\title{
Models of Regional Development in Russia: Level of Industrialisation and Innovative Performance
}

\author{
Yuri A. Doroshenko, Maria S. Starikova, Viktoriia N. Riapukhina
}

Belgorod State Technological University named after V.G. Shukhov

Kostyukova st. 46, 308012, Belgorod, Russian Federation

E-mail.549709@mail.ru; s_ms@bk.ru; viktorer_r@mail.ru

cross $^{\text {ref }}$ http://dx.doi.org/10.5755/j01.ee.32.3.25897

\begin{abstract}
The growth in the share of industry in the structure of Gross Domestic Product due to an increase in its competitiveness, causes a multiplier effect of accelerating economic growth, reducing unemployment and developing social and transport infrastructure. All these imperatives actualise the task of deepening the analysis of the level of industrialisation and innovative performance of the national economy and its regions. To achieve this goal, a theoretical analysis of the relationship between industrial growth and innovation activity was carried out, and the problems of industrial growth of the Russian economy were identified. The proposed toolkit is based on assessing the level of industrialization and innovative performance of the region. Based on their comparison, four models of industrial and innovative development are distinguished: model of non-industrial development, model of post-industrial development, model of neo-industrial development, and model of industrial development. According to the results of the study, the structure of Russian regions by the type of industrial-innovative development model is relatively stable and insufficiently progressive. Only a third of the regions have high innovative performance. The lack of the required balance between the development of industrial potential and the innovative productivity of Russian regions is associated with the low efficiency of the applied industrial policy measures. The research results can be useful for assessing the quality of industrial growth of regions in countries with transitional economies.
\end{abstract}

Keywords: Regional Development; Industrial Growth; The Share of Innovative Products in Industrial Output, Innovative Performance; Post-Industrial Development; Neo-Industrial Development; Non-Industrial Development; Industrial Development.

\section{Introduction}

It has long been established that the accelerated economic growth of developed countries depends on industrial revolutions. Criticism of the post-industrial economic development paradigm resulting from the loss of jobs and competitive advantages in high-tech industries is accompanied by ideas regarding the need to achieve innovative growth through modernisation and reindustrialisation. The neoindustrialization (reindustrialization) model received theoretical justification in the second half of the 20th century (Galbraith, 1967), however, it began to be applied only when developed countries exhausted opportunities for growth through previous instruments. It is currently being implemented as a part of the concept of the fourth industrial revolution (4IR), that is based on the growing convergence of different emerging technology domains (digital production technologies, nanotechnologies, biotechnologies and new materials) and their complementarity in production.

Currently, there are many factors that scientists attribute to the possibility of accelerating economic growth. This includes an influx of skilled labour (Tipayalai, 2020) and even just population growth (Madsen et al., 2010). Some studies, particularly regarding the example of the dynamics of European Integration (Kallioras \& Petrakos, 2010), reveal the negative impact of excessive consolidation of various economies on industrial growth. However, according to the results of other studies, the unification of innovation-weaker countries leads to the faster growth of their innovation dynamics (Krajco et al., 2019). Along with this, the highest degree of convergence as a result of economic integration of countries is achieved in growth rates of real output in all groups of economies (Oplotnik et al., 2011).

Scientists also note the need for digitalization of not only production, but also human capital, and organizational capital (Schneider, 2018). An interesting conclusion shows that the longer the distance to the high level of industrial development of the territory in the past, the higher the level of its economic development at the present time. This gives hope to regions with low industrial potential to expect high economic results in the future (Ozak, 2018). However, naturally, there must be some prerequisites for such progress.

One of the lessons we can take from the Great Recession is that countries with a higher share of industry in their GDP were less affected by the crisis. Therefore, we agree with the statement that one of the most significant factors of economic growth is the innovative development of industry (Jungmittag, 2004). On the one hand, the criterion for the effectiveness of the transition to a new stage of technological development is considered to be such a level of development of the manufacturing industry, which not only meets the needs of the home territory, but also has a high export component. On the other hand, the need for innovative development of extractive industries has also been proven by scientists (Litvinenko \& Sergeev, 2019). 
So, despite the multiplicity of sources of economic growth, the most significant source of growth in the context of the instability of the global economy and the vulnerability of national economic systems is neo-industrialization, which provides a qualitatively new level of industrial development based on innovations.

The logic of the article's presentation assumes, first of all, identification of aspects of the relationship between industrial growth and innovative development in world studies, and secondly, consideration of theoretical prerequisites of neo-industrialisation in Russia and substantiation of the importance of industrial growth supported by innovations. The third part of the article presents the research methodology that allows not only to determine the degree of connection between industrial development and the innovative performance of Russian regions, but also to establish the type of territorial model of industrial and innovative development used. The fourth part of the article contains the results of the analysis of industrial and innovative development of Russian regions and their discussion. In the final part, conclusions are given and directions for further research are formulated.

\section{Theoretical Foundations of the Relationship between Industrial Growth and Innovative Development}

Our analysis of publications on the topic of this study shows that the relationship between industrial growth and innovative development of regions is confirmed by researchers from different countries of the world. It was found that the relationship between industrial growth and innovation activity occurs in different areas, namely:

1. Sustainable development. The neo-industrialization of regional economic systems is viewed in the context of sustainable industrial development, which predetermines the focus of innovation on environmental protection and the efficient use of non-renewable resources (Ulbrych, 2020), as well as on the search for ways to overcome the industrial crisis in our post-Covid 19 societies (Ferrannini et al., 2020).

2. Organizational and technological improvement of regional enterprises. The consolidation of Chinese manufacturing companies through international expansion and M\&As abroad leads to an increase in the country's innovative potential (Petti et al., 2019). European studies of neo-industrialization deal with the problem of stabilizing the global value chain based on innovative vectors aimed at reducing dependence on imports, accelerating the transition to a digital and low-carbon economy, increasing the transparency of interactions between participants in the chain (Mateus \& Martins, 2020). The organizational aspect is also showed in the study of industrial clusters, the geographical proximity of enterprises in which contributes to the development of proximity in other dimensions: social, competence and innovative (Lis, 2020). With the advent of the Fourth Industrial Revolution, the issues of introducing innovations into the business models of enterprises through digital transformation are relevant (van Tonder et al., 2020). Everywhere and in Asian countries, in particular, technological innovations are considered as the basis for updating and adapting the business processes of manufacturing companies to the challenges of the digital economy (Li et al., 2020).
3. Formation of human capital. India's experience demonstrates the high importance of improving the quality of higher education in order to form a qualified technical workforce to increase the share of industrial production in GDP and enhance its innovative content (Hariharan \& Biswas, 2020). The importance of developing digital skills of the workforce for ensuring the sustainability of economic development in the context of Industry 4.0, based on the digitalization of production processes, is highlighted in an article by European scientists (Habanik et al., 2019). Researchers from China and Pakistan state the crucial importance of intellectual capital and innovation policy for manufacturing companies in the context of the fourth industrial revolution ( $\mathrm{Li}$ et al., 2021). Improving human capital contributes to the growth of the effectiveness of technological innovation, strengthening the link between technological innovation and spillovers (Hu, 2021). Improving the quality of human capital and technological innovation, as well as continuous investment in $R \& D$, make the production sector and the national economy more productive (Gu et al., 2021).

4. Interaction with subjects of the innovation environment. The industrial strategy of the UK emphasizes the key role of the interaction of universities with industrial enterprises (Johnston \& Wells, 2020). The expediency of cooperation with universities is confirmed by studies that have shown a more developed ability of university business incubators to create innovations of global novelty compared to technology incubators, which tend to create local innovations (Goraczkowska, 2020). It is proved that innovations not only of large corporations, but also of anchor entrepreneurs play a significant role in the origin and development of agglomerations and clusters. Anchor entrepreneurs are a dynamic force and catalyst for new industrial formations (Ferriani et al., 2020). Based on the example of regional studies carried out in Poland, it is substantiated that the stimulation of innovative cooperation for the development of industry is advisable in advanced territories. In underdeveloped regions, it is necessary to stimulate innovation as such. (Swiadek \& Goraczkowska, 2020).

5. Export. A study of data from Chinese industrial companies over a seven-year period showed that market size affects the innovation activity of enterprises in the region less than their export activities (Cai et al., 2020). The inverse relationship between these parameters is also confirmed: the activation of innovations, especially in terms of marketing, contributes to an increase in the export activity of regional enterprises in Uruguay (Horta et al., 2020).

Despite the existence of many points of contact between industrial development and innovation, we believe that their relationship is most strongly manifested in the creation of innovative products. The relationship between the effectiveness of innovation and the development of the industrial sector of the economy is emphasized, for example, by H. Kroll, P. Neuhausler, who substantiated the need to match the technological development of industry with the effectiveness of economic activity, expressed, among other things, in the growth of innovative productivity (Kroll \& Neuhausler, 2020). In this regard, further research is carried out in the context of determining the innovative performance of the industrial development of Russian 
regions. However, before proceeding to a methodological description of the proposed research tools, we consider it necessary to describe the main problems of the industrial development of Russian regions.

\section{Problems of Industrial Development in Russia}

Neo-industrialisation as a global trend and imperative of the innovation trajectory of national economies postulates the key role of industry, and especially its part related to the use of advanced technologies, for achieving competitive economic growth. The need to understand at a state-level the importance for Russia (as well as for other transition economies) of industrial development, supported by the growth of output of innovative products, is due to several theses emphasised in various studies (Klyuev, 2018; Kornev et al., 2015; Kaneva, 2017; Benini \& Czyzewski, 2007; Doroshenko et al., 2016):

1. The property of any industrial revolution is the unevenness of its translation into the world space. Scientific ideas and developments change the economic landscape only if there is a technological restructuring of economic systems and a multiple increase in the use of the achievements of the industrial revolution. That is why it is important to level the industrial development of regional economies within the country and ensure their compliance with innovative transformations.

2. According to the Industrial Development Report $2020^{1}$, Russia is among the 50 economies actively developing and implementing advanced digital technologies (ADP), however, not as a leader, but as a follower. It should also be noted that the introduction of advanced digital production continues to have limitations in developing countries. Therefore, in fast-growing economies, industrial growth is accompanied by increased productivity, while in developing countries productivity remains low even as industrial production grows.

3. Re-industrialisation implemented after deindustrialisation is considered to be more complicated than early industrialisation. Increasing the share of industrial production in the country's GDP and in the total number of employed people in the economy in the 21 st century requires much more effort than before.

4. The opportunities to effectively eliminate the disparity in the innovative and industrial development of Russian regions are associated with the spread of positive experience of using the agglomeration effect in the capital.

5. Spending on technological innovations and the quality of institutions in Russia have the most significant positive impact on the level of economic activity and economic growth in the regions.

The development of the industrial sector determines the speed and quality of economic growth. Although against the background of global statistics Russian industrialisation indicators generally correspond to general trends ${ }^{2}$, the qualitative component of Russia's industrial sector is largely

\footnotetext{
${ }^{1}$ Industrial Development Report 2020. Industrializing in the digital age Overview. Available from the Internet: https://www.unido .org/sites/default/files/files/2019-11/UNIDO_IDR2020-

English_overview.pdf.
}

inferior to developed countries due to the lack of significant growth in the manufacturing industry. The weak dynamics of the industrial production index of the Russian Federation in $2015-99.2 \%$, in $2016-102.2 \%$, in $2017-102.1 \%$, in $2018-102.9 \%$ ) is mainly due to a positive trend in mining. At the same time, in Germany this indicator was 111,112 , 116,117 in 2015, 2016, 2017, 2018 respectively, in the USA - 111, 108, 111, 115, in India - 114, 120, 124, 13032. Russia's development dynamics are characterised by a qualitative improvement of the industrial component only in the period from 2011 to 2014, and further growth of the industrial sector's contribution to Gross Domestic Product was accompanied by a decrease in the level of innovativeness of products (Fig. 1).

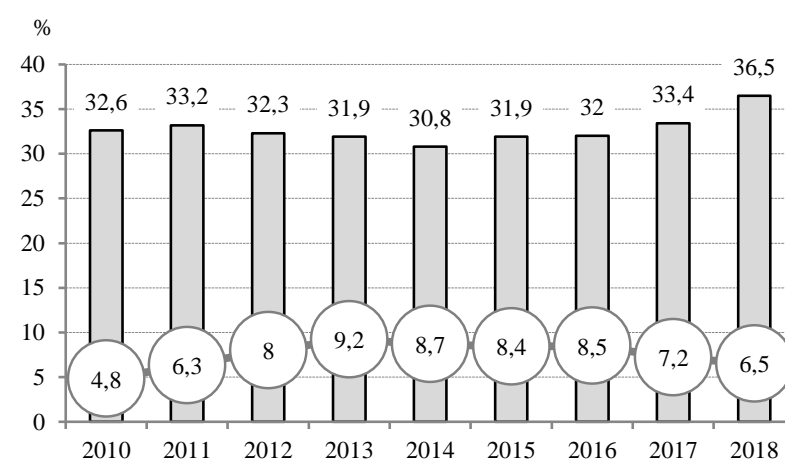

$$
\begin{aligned}
& \text { Share of industry in GDP } \\
& \text { The share of innovative goods in the total volume of delivered } \\
& \text { goods, works, services }
\end{aligned}
$$

Figure 1. The Dynamics of Industrial and Innovative Development of the Russian Federation

The explanation of the dynamics given in Fig. 1 is the fact that Russia, with its historically developed export-raw material model of the economy, maintains high profitability of production and the export of raw materials while at the same time low profitability of the manufacturing industry. Overcoming the stagnation of development characterised by the increase of the financial sector, trade, and services, is possible only if the outstripping growth of mechanical engineering, electronic industry and construction in relation to GDP growth is achieved. The formula for development in Russia is considered to be vertical integration plus neoindustrialisation (Gubanov, 2017). Experts note that in order accelerate the appearance of signs of the fourth industrial revolution in Russia, it is important to increase the contribution of the manufacturing industry to added value, to increase the level of commercialization of innovations, to intensify the participation of small businesses in the innovation process, to improve models of interaction between the high-tech sector and the subjects of the innovation environment. (Schetinina et al., 2014; Doroshenko et al., 2019).

\footnotetext{
${ }^{2}$ List of Countries by GDP Sector Composition. Available from the Internet: http://statisticstimes.com/economy/countries-by-gdpsector-composition.php.

${ }^{3}$ Federal State Statistic Service. Available from the Internet: https://www.gks.ru/incomparisons.
} 
As a result of the theoretical analysis of the scientific problem, we can state that there is no congruence between external challenges and the state of the industrial base of the Russian economy, which underlines the urgency of the problem of studying the industrial potential of Russian regions in the context of the ability to create an innovative product.

\section{Research method}

The methodology of the proposed analysis is based on assessing whether the level of industrialization of regions determines their ability to produce innovative goods. Regression equations and correlation coefficients are used as analysis tools. They make it possible to identify the nature and degree of the relationship between the level of industrialization and the innovative performance of the region. The procedure for calculating the level of industrialization and innovative performance of the region is given in table. 1 .

Table 1

Indicators to Analyse the Relationship between Industrial Development and Innovative Efficiency of Russian Regions

\begin{tabular}{|l|l|l|}
\hline \multicolumn{1}{|c|}{ Indicator } & Interpretation & \multicolumn{1}{c|}{ Calculation } \\
\hline $\begin{array}{l}\text { Level of } \\
\text { industrialisation }\end{array}$ & $\begin{array}{l}\text { contribution of } \\
\text { all industry } \\
\text { sectors to the } \\
\text { Gross Regional } \\
\text { Product }\end{array}$ & $\begin{array}{l}\text { sum of the gross value } \\
\text { added in the extractive } \\
\text { and manufacturing } \\
\text { industries }\end{array}$ \\
\hline $\begin{array}{l}\text { Innovative } \\
\text { performance }\end{array}$ & $\begin{array}{l}\text { share of } \\
\text { innovative } \\
\text { products in } \\
\text { industrial output }\end{array}$ & $\begin{array}{l}\text { volume of innovative } \\
\text { goods produced in the } \\
\text { region, correlated with } \\
\text { the volume of output of } \\
\text { domestically produced } \\
\text { goods }\end{array}$ \\
\hline
\end{tabular}

Note: Indicators are calculated on the basis of Rosstat data.

Comparison of the level of industrialization and innovative performance of the region allows us to determine the type of model of industrial and innovative development used in the region (Fig. 2).

In addition, data analysis within the framework of the proposed methodological approach allows us to determine the type of industrial and innovative development model used in the region.

The critical value that defines the middle of each axis in the matrix is the average value of the indicator for the Russian Federation.

Models of regional industrial and innovative development (MRIID) may be given the following characteristics:

1. The model of non-industrial development is typical for regions with a relatively low level of industrialisation and a small share of innovative production in industrial output. These are mainly regions with agricultural or service specialisation.

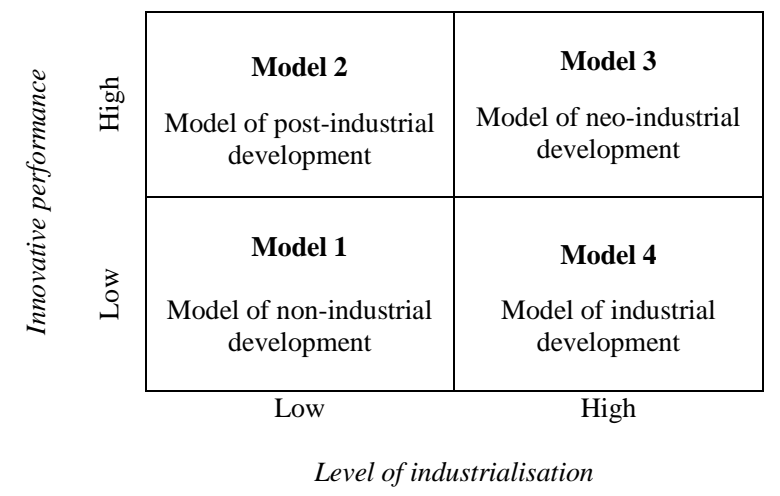

Figure. 2. Models of regional industrial and innovative development

Composed by the author

2. The model of post-industrial development occurs in regions with relatively low levels of industrialisation and a high share of innovative products in industrial output. The economic structure of these regions is in line with the ideology of the post-industrial economy (the contribution of the services sector to Gross Regional Product is high); however, the industrial sector in these regions is mainly of a high-tech nature, and this makes it possible to produce a relatively high percentage of innovative products.

3. The model of neo-industrial development highlights the regions that are the reference points for innovative development in the context of the fourth industrial revolution, as they demonstrate a relatively high contribution of industry to Gross Regional Product, which is accompanied by a relatively large share of innovative products in total industrial output.

4. The model of industrial development is typical for old industrial regions, which use low and medium-tech industries and are slow to implement technological modernisation programmes, which, as a result, complicates the growth of their industrial output of innovative products.

\section{Research Results and Discussion}

Estimation of the relationship between the level of industrialisation and innovative performance by all subjects of the Russian Federation for 2014 and 2018. (Table 2) shows that the relationship between the studied parameters becomes less determined and the nature of the relationship changes (from direct to inverse).

On the one hand, this proves that it is difficult to achieve innovative performance by developing the industrial sector without corresponding modernisation of the research base and innovation infrastructure. On the other hand, the analysis highlights the slowdown in the innovation processes of the Russian regions' economies: while in 2014 the correlation between the level of industrialisation and the innovation performance was weak, in 2018 it is completely absent 
Table 2

Relationship between the Level of Industrialisation (Axis x) and the Innovative Performance (axis y) in the Subjects of the Russian Federation

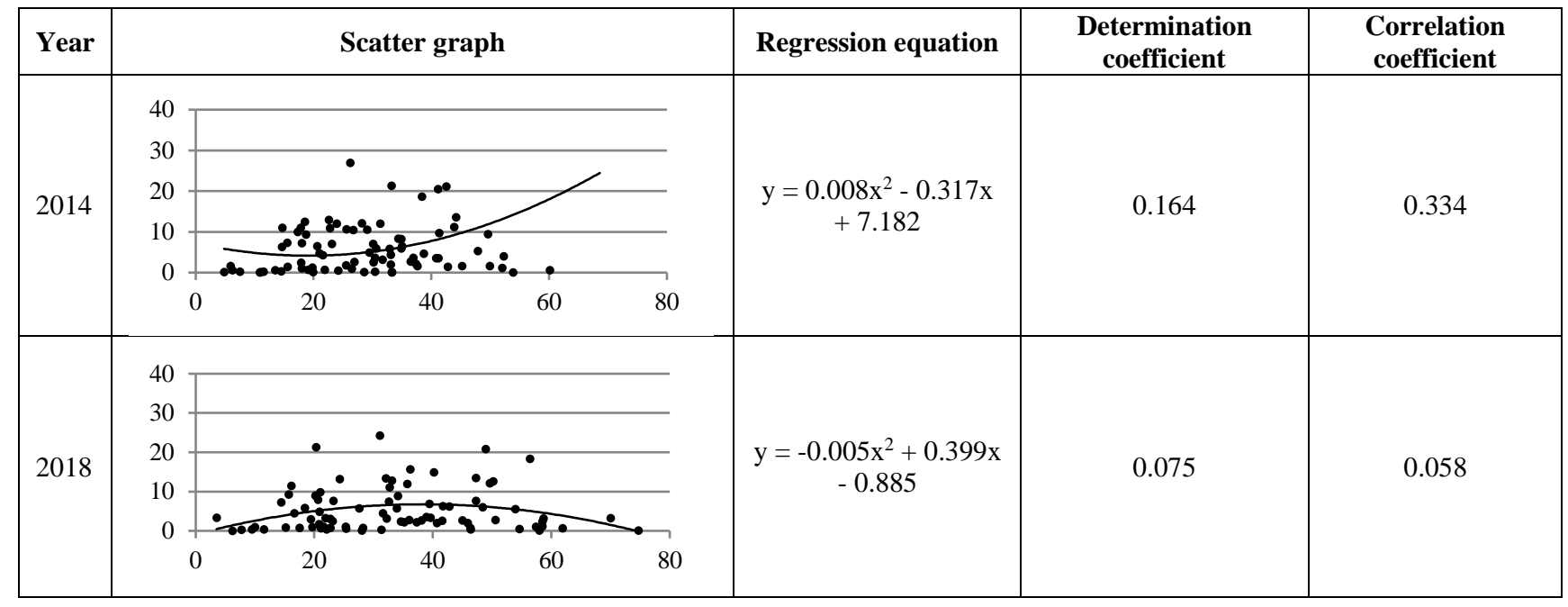

Composed by the author

It can be stated that for 2018 in the Russian regions there was no stable and deterministic relationship between the level of industrialization and innovative performance.
A summary of the statistical data and the results for determining the type of innovation development model used are presented in Table 3.

Table 3

Defining the Model of Industrial and Innovative Development of Russian Regions in 2014 and 2018

\begin{tabular}{|c|c|c|c|c|c|c|}
\hline \multirow{2}{*}{$\begin{array}{c}\text { The subject of the } \\
\text { Russian } \\
\text { Federation }\end{array}$} & \multicolumn{2}{|c|}{2014} & \multicolumn{2}{|c|}{2018} & \multirow{2}{*}{$\begin{array}{l}\text { MRIID } \\
-2014\end{array}$} & \multirow{2}{*}{$\begin{array}{c}\text { MRIID } \\
-2018\end{array}$} \\
\hline & $\begin{array}{c}\text { Level of } \\
\text { industrialisation }\end{array}$ & $\begin{array}{c}\text { Innovative } \\
\text { performance }\end{array}$ & $\begin{array}{c}\text { Level of } \\
\text { industrialisation }\end{array}$ & $\begin{array}{c}\text { Innovative } \\
\text { performance }\end{array}$ & & \\
\hline Voronezh Region & 18 & 7.2 & 18.4 & 5.9 & 1 & 1 \\
\hline Rostov Region & 22.8 & 10.9 & 27.6 & 5.8 & 2 & 1 \\
\hline $\begin{array}{l}\text { Novosibirsk } \\
\text { Region }\end{array}$ & 17.3 & 10 & 20.9 & 4.9 & 2 & 1 \\
\hline Tver Region & 25.5 & 1.8 & 31.6 & 4.5 & 1 & 1 \\
\hline Sevastopol & 24.2 & 0.5 & 16.6 & 4.5 & 1 & 1 \\
\hline $\begin{array}{l}\text { Republic of } \\
\text { Kalmykia }\end{array}$ & 4.8 & 0.1 & 3.5 & 3.4 & 1 & 1 \\
\hline Bryansk Region & 20.6 & 6.5 & 21.9 & 3.3 & 1 & 1 \\
\hline Kurgan Region & 26.9 & 2.6 & 32.2 & 3.2 & 1 & 1 \\
\hline Pskov Region & 19.1 & 0.7 & 22.7 & 3.1 & 1 & 1 \\
\hline Moscow & 14.7 & 11 & 19.4 & 3 & 2 & 1 \\
\hline Altai Krai & 21.6 & 4.3 & 23.1 & 2.5 & 1 & 1 \\
\hline $\begin{array}{l}\text { Jewish } \\
\text { Autonomous } \\
\text { Oblast }\end{array}$ & 13.5 & 0.6 & 20.8 & 1.8 & 1 & 1 \\
\hline Kamchatka Krai & 19.8 & 1.2 & 25.3 & 1.1 & 1 & 1 \\
\hline Amur Region & 21 & 4.7 & 21.6 & 1.1 & 1 & 1 \\
\hline Orel Region & 18 & 1 & 19.7 & 1 & 1 & 1 \\
\hline Altai Republic & 7.5 & 0.2 & 10 & 1 & 1 & 1 \\
\hline $\begin{array}{l}\text { Kabardino- } \\
\text { Balkarian Republic }\end{array}$ & 17.9 & 2.4 & 15.2 & 0.9 & 1 & 1 \\
\hline Murmansk Region & 30.4 & 3.6 & 28.2 & 0.8 & 1 & 1 \\
\hline Republic of Crimea & 21.9 & 0.7 & 17.5 & 0.8 & 1 & 1 \\
\hline Zabaykalsky Krai & 15.5 & 7.3 & 22.7 & 0.8 & 1 & 1 \\
\hline $\begin{array}{l}\text { The Republic of } \\
\text { Buryatia }\end{array}$ & 25.6 & 10.6 & 21.1 & 0.7 & 2 & 1 \\
\hline
\end{tabular}

Continuation of Table 3 
Yuri A. Doroshenko, Maria S. Starikova, Viktoriia N. Riapukhina. Models of Regional Development in Russia: Level of ...

\begin{tabular}{|c|c|c|c|c|c|c|}
\hline \multirow{2}{*}{$\begin{array}{l}\text { The subject of } \\
\text { the Russian } \\
\text { Federation }\end{array}$} & \multicolumn{2}{|c|}{2014} & \multicolumn{2}{|c|}{2018} & \multirow{2}{*}{$\begin{array}{c}\text { MRIID } \\
-2014\end{array}$} & \multirow{2}{*}{$\begin{array}{l}\text { MRIID } \\
-2018\end{array}$} \\
\hline & $\begin{array}{c}\text { Level of } \\
\text { industrialisation }\end{array}$ & $\begin{array}{c}\text { Innovative } \\
\text { performance }\end{array}$ & $\begin{array}{c}\text { Level of } \\
\text { industrialisation }\end{array}$ & $\begin{array}{c}\text { Innovative } \\
\text { performance }\end{array}$ & & \\
\hline Ivanovo Region & 26.5 & 0.9 & 25.4 & 0.6 & 1 & 1 \\
\hline $\begin{array}{l}\text { The Republic of } \\
\text { Ingushetia }\end{array}$ & 11.5 & 0.2 & 11.5 & 0.4 & 1 & 1 \\
\hline $\begin{array}{l}\text { The Karachay- } \\
\text { Cherkess Republic }\end{array}$ & 19.9 & 0.1 & 22.1 & 0.4 & 1 & 1 \\
\hline $\begin{array}{l}\text { The Republic of } \\
\text { North Ossetia - } \\
\text { Alania }\end{array}$ & 11 & 0.1 & 9.5 & 0.4 & 1 & 1 \\
\hline $\begin{array}{l}\text { Kaliningrad } \\
\text { Region }\end{array}$ & 33.3 & 0.1 & 31.3 & 0.3 & 4 & 1 \\
\hline $\begin{array}{l}\text { The Republic of } \\
\text { Dagestan }\end{array}$ & 6.2 & 0.6 & 7.7 & 0.3 & 1 & 1 \\
\hline $\begin{array}{l}\text { The Tyva } \\
\text { Republic }\end{array}$ & 10.9 & 0 & 28 & 0.1 & 1 & 1 \\
\hline $\begin{array}{l}\text { The Chechen } \\
\text { Republic }\end{array}$ & 5.9 & 1.6 & 6.2 & 0 & 1 & 1 \\
\hline $\begin{array}{l}\text { The Republic of } \\
\text { Mordovia }\end{array}$ & 26.2 & 26.9 & 31.1 & 24.3 & 2 & 2 \\
\hline Khabarovsk Krai & 18.5 & 12.5 & 20.3 & 21.3 & 2 & 2 \\
\hline Ulyanovsk Region & 31.3 & 12 & 32.1 & 13.4 & 3 & 2 \\
\hline Moscow Region & 22.6 & 12.9 & 24.3 & 13.2 & 2 & 2 \\
\hline $\begin{array}{l}\text { Yaroslavskaya } \\
\text { Oblast }\end{array}$ & 29.1 & 10.5 & 33.1 & 12.8 & 2 & 2 \\
\hline Krasnodar Krai & 15.6 & 1.4 & 16.1 & 11.5 & 1 & 2 \\
\hline $\begin{array}{l}\text { The Chuvash } \\
\text { Republic - } \\
\text { Chuvashia }\end{array}$ & 28.2 & 12.1 & 32.7 & 11.1 & 2 & 2 \\
\hline Saint Petersburg & 23.9 & 12 & 21 & 9.9 & 2 & 2 \\
\hline Tambov Region & 14.6 & 6.3 & 15.7 & 9.3 & 1 & 2 \\
\hline Stavropol Krai & 17.8 & 11 & 20.2 & 9 & 2 & 2 \\
\hline $\begin{array}{l}\text { The Republic of } \\
\text { Adygea }\end{array}$ & 18.7 & 9.3 & 20.6 & 8 & 2 & 2 \\
\hline Penza Region & 23.1 & 7 & 23.2 & 7.7 & 1 & 2 \\
\hline Kostroma Region & 33.1 & 2 & 32.6 & 7.5 & 4 & 2 \\
\hline Primorsky Krai & 14.5 & 0.3 & 14.4 & 7.3 & 1 & 2 \\
\hline $\begin{array}{l}\text { The Republic of } \\
\text { Tatarstan }\end{array}$ & 41.1 & 20.5 & 48.9 & 20.9 & 3 & 3 \\
\hline Perm Krai & 49.6 & 9.4 & 56.4 & 18.4 & 3 & 3 \\
\hline $\begin{array}{l}\text { Nizhny Novgorod } \\
\text { Region }\end{array}$ & 33.2 & 21.3 & 36.2 & 15.7 & 3 & 3 \\
\hline Belgorod Region & 33.1 & 4.4 & 40.2 & 14.9 & 4 & 3 \\
\hline Samara Region & 42.5 & 21.1 & 47.3 & 13.5 & 3 & 3 \\
\hline $\begin{array}{l}\text { The Udmurt } \\
\text { Republic }\end{array}$ & 43.9 & 11.2 & 50.2 & 12.6 & 3 & 3 \\
\hline Tula Region & 41.3 & 9.7 & 49.6 & 12.2 & 3 & 3 \\
\hline Kursk Region & 35 & 6.5 & 35.7 & 12 & 4 & 3 \\
\hline Kirov Region & 30.1 & 7 & 34.1 & 8.9 & 1 & 3 \\
\hline Lipetsk Region & 44.2 & 13.6 & 47.3 & 7.7 & 3 & 3 \\
\hline $\begin{array}{l}\text { Sverdlovsk } \\
\text { Region }\end{array}$ & 32.9 & 5.8 & 39.4 & 6.9 & 4 & 4 \\
\hline $\begin{array}{l}\text { The Republic of } \\
\text { Bashkortostan }\end{array}$ & 34.9 & 8.2 & 41.7 & 6.3 & 4 & 4 \\
\hline $\begin{array}{l}\text { Chelyabinsk } \\
\text { Region }\end{array}$ & 38.7 & 4.6 & 42.8 & 6.2 & 4 & 4 \\
\hline Irkutsk Region & 37.6 & 1.6 & 48.4 & 6.1 & 4 & 4 \\
\hline Ryazan Region & 31.7 & 3.2 & 33.9 & 5.8 & 4 & 4 \\
\hline $\begin{array}{l}\text { Arhangelsk } \\
\text { Region }\end{array}$ & 42.8 & 1.4 & 53.9 & 5.6 & 4 & 4 \\
\hline Vladimir Region & 34.4 & 8.3 & 38.9 & 3.6 & 4 & 4 \\
\hline Omsk Region & 40.8 & 3.5 & 39.6 & 3.4 & 4 & 4 \\
\hline Tyumen Region & 60.1 & 0.6 & 70 & 3.3 & 4 & 4 \\
\hline
\end{tabular}

End of Table 3 
Inzinerine Ekonomika-Engineering Economics, 2021, 32(3), 247-257

\begin{tabular}{|c|c|c|c|c|c|c|}
\hline \multirow{2}{*}{$\begin{array}{l}\text { The subject of } \\
\text { the Russian } \\
\text { Federation }\end{array}$} & \multicolumn{2}{|c|}{2014} & \multicolumn{2}{|c|}{2018} & \multirow{2}{*}{$\begin{array}{c}\text { MRIID } \\
-2014\end{array}$} & \multirow{2}{*}{$\begin{array}{c}\text { MRIID } \\
-2018\end{array}$} \\
\hline & $\begin{array}{c}\text { Level of } \\
\text { industrialisation }\end{array}$ & $\begin{array}{c}\text { Innovative } \\
\text { performance }\end{array}$ & $\begin{array}{c}\text { Level of } \\
\text { industrialisation }\end{array}$ & $\begin{array}{c}\text { Innovative } \\
\text { performance }\end{array}$ & & \\
\hline Orenburg Region & 52 & 1.1 & 58.7 & 3.2 & 4 & 4 \\
\hline $\begin{array}{l}\text { The Mari El } \\
\text { Republic }\end{array}$ & 26.7 & 10.4 & 36 & 2.8 & 2 & 4 \\
\hline $\begin{array}{l}\text { The Republic of } \\
\text { Khakassia }\end{array}$ & 33.3 & 0 & 50.6 & 2.8 & 4 & 4 \\
\hline Kaluga Region & 36.5 & 2.7 & 45 & 2.7 & 4 & 4 \\
\hline Leningrad Region & 34.9 & 5.9 & 38.1 & 2.7 & 4 & 4 \\
\hline $\begin{array}{l}\text { The Republic of } \\
\text { Karelia }\end{array}$ & 30.4 & 0.2 & 41.6 & 2.6 & 1 & 4 \\
\hline Saratov Region & 30.2 & 2.5 & 34.6 & 2.4 & 1 & 4 \\
\hline Kemerovo Region & 45.2 & 1.6 & 58.5 & 2.4 & 4 & 4 \\
\hline Smolensk Region & 30.6 & 5.9 & 35.2 & 2.2 & 1 & 4 \\
\hline Volgograd Region & 37.4 & 2.1 & 37.3 & 2.2 & 4 & 4 \\
\hline Vologda Region & 38.4 & 18.6 & 45.9 & 2 & 3 & 4 \\
\hline Novgorod Region & 36.9 & 3.6 & 40.7 & 2 & 4 & 4 \\
\hline The Komi Republic & 47.9 & 5.3 & 58.5 & 1.2 & 4 & 4 \\
\hline $\begin{array}{l}\text { The Republic of } \\
\text { Sakha (Yakutia) }\end{array}$ & 49.9 & 1.6 & 57.4 & 1.1 & 4 & 4 \\
\hline Tomsk Region & 41.2 & 3.5 & 46.3 & 0.8 & 4 & 4 \\
\hline Krasnoyarsk Krai & 52.3 & 4 & 61.9 & 0.7 & 4 & 4 \\
\hline $\begin{array}{l}\text { Chukotka } \\
\text { Autonomous Okrug }\end{array}$ & 53.9 & 0 & 54.6 & 0.5 & 4 & 4 \\
\hline Magadan Region & 28.6 & 0.1 & 46.4 & 0.4 & 1 & 4 \\
\hline Astrakhan Region & 29.5 & 4.9 & 58 & 0.1 & 1 & 4 \\
\hline Sakhalin Region & 68.6 & 60.1 & 74.7 & 0.1 & 3 & 4 \\
\hline
\end{tabular}

Source: Rosstat data [Electronic resource]. URL: http://www.gks.ru/wps/wcm/connect/rosstat_main/rosstat/ru/statistics/accounts/\#,

Russian regions. Socio-economic indicators. (2018) Collected papers / Rosstat. M. P. 1162, Regions of Russia. Socio-economic indicators. (2015) Collected papers / Rosstat. M. P. 1266, and authors calculations.

The assessment showed that practically in all regions of Russia there was no "revolutionary" growth in the level of industrialization (such as to exceed the average Russian level). Only seven subjects of the Russian Federation (Kostroma, Tambov, Belgorod, Kursk, Kirov regions, Krasnodar \& Primorsky Krai) demonstrated in 2014-2018 increase in innovative performance, indicating a transition to a more progressive model of regional development. During the same period, only seven subject of the Russian Federation (the Republic of Karelia and Mari-El, Astrakhan, Kirov, Magadan, Saratov, Smolensk regions) showed an increase in the level of industrialization, which allowed them to move to the zones of the matrix of models of industrial and innovative development, indicating an increase in the efficiency of the regional politicians. Note that the level of industrialization of regions producing a high share of innovative products in the volume of industrial output is in the range from 14.4 to $56.4 \%$ (for all Russian regions this interval is 3.5-74.7).

A correlation-regression analysis (Table 4) has been conducted for the identified models, which establishes the highest level of determination and correlation ratio between the investigated parameters in the regions implementing the industrial development model and the neo-industrial development model.

Table 4

Relationship between the Level of Industrialisation (axis $\mathbf{x}$ ) and the Innovative Performance (axis $y$ ) in the Subjects of the Russian Federation with Different Types of MRIID in 2018

\begin{tabular}{|c|l|c|c|}
\hline MRIID type & Regression equation & Determination coefficient & Correlation coefficient \\
\hline 1 & $\mathrm{y}=0.045 \mathrm{x}+1.031$ & 0.037 & 0.194 \\
\hline 2 & $\mathrm{y}=3.036 \mathrm{x}^{0.41}$ & 0.107 & 0.287 \\
\hline 3 & $\mathrm{y}=0.014 \mathrm{x}^{2}-1.076 \mathrm{x}+32.3$ & 0.161 & 0.367 \\
\hline 4 & $\mathrm{y}=-0.000 \mathrm{x}^{2}+0.008 \mathrm{x}+4.574$ & 0.182 & -0.424 \\
\hline
\end{tabular}

It is necessary to emphasise that the model of neoindustrial development is characterised by a direct relationship between the level of industrialization and the innovative performance of the region, while the model of industrial development is characterised by an inverse relationship between these parameters. The transition of regions implementing the model of industrial development to the model of neo-industrial development is possible on the basis of the reduction and modernization of low-tech industries, an increase in the innovative activity of companies and the opening of new innovative technological sites.

A further increase in the level of industrialisation within the framework of the existing policy of technological modernisation in the regions implementing model 3 will strengthen the established direct correlation ratio between the level of industrialisation and the innovative performance. Regions implementing models 1 and 2 require government support for their industrial growth and competitiveness. 
It should be noted that during the analysed period the regional structure of the Russian Federation, considered

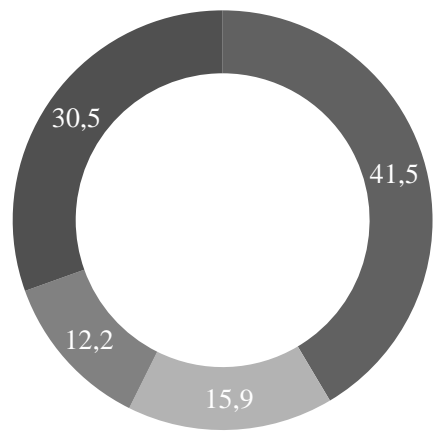

\begin{abstract}
1. Model of non-industrial development
2. Model of post-industrial development

-3. Model of neo-industrial development

- 4. Model of industrial development
\end{abstract}

\section{4}

through the prism of the models proposed in the article, has improved (Fig. 3).

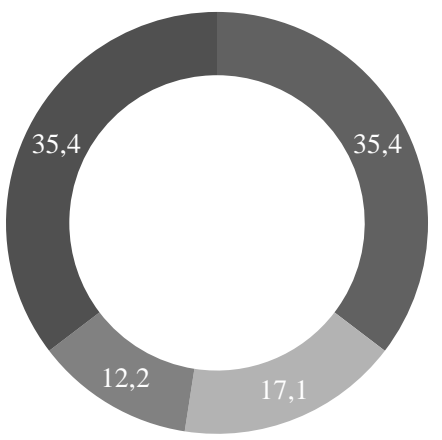

\begin{abstract}
1. Model of non-industrial development
2. Model of post-industrial development

3. Model of neo-industrial development

4. Model of industrial development
\end{abstract}

Figure 3. Regional Structure of the Russian Federation According to the type of Industrial and Innovative Development Model

The share of regions with a high contribution of innovative products to industrial output (models 2 and 3) expanded from $28.1 \%$ in 2014 to $29.3 \%$ in 2018 , which positively characterizes the industrial policy being implemented in them.

In 2018, a post-industrial development model is being formed in $17.1 \%$ of Russian regions, and only $12.2 \%$ of Russian regions have a neo-industrial development model. According to the data of 2018, it can be stated that $70.7 \%$ of Russian regions have a level of innovative performance below the average for the Russian Federation, of which: $35.4 \%$ of the subject of the Russian Federation implement the model of non-industrial development, $35.4 \%$ of Russian regions use the model of industrial development.

A positive trend is that the share of regions implementing the model of non-industrial development has decreased, while the share of subjects of the Russian Federation using the model of neo-industrial development and the model of industrial development has increased. The share of regions with a relatively higher level of industrialization (models 1 and 4 ) has grown from $42.7 \%$ in 2014 to $47.6 \%$ in 2018.

\section{Conclusions}

With the crisis of the post-industrial doctrine and the exhaustion of the former sources of economic growth, the difficulty of overcoming the consequences of deindustrialisation is seen as the main factor constraining economic development. Intensive restoration of the role of industry in ensuring sustainable economic dynamics is implemented in the format of industrial policy of neoindustrialisation and is identified as a priority task of state and regional management of economic development in the context of prolonged stagnation and technological lag.

A theoretical analysis of the world experience in researching the problem outlined in the article showed that industrial development and innovative activity have points of contact in many aspects, namely: achieving sustainable development, organizational and technological improvement of business, improving the quality of human capital, interaction with the subjects of the innovative environment, and development of export activities. We support the idea that in the context of the fourth industrial revolution, the strongest relationship between industrial development and innovation is demonstrated in the creation of innovative products.

The solution of the problems of industrial development of Russian regions in modern conditions is illusory without an increase in the level of industrialization of the regions, supported by innovative performance. The proposed methodological approach is based on assessing the relationship between the level of industrialization and innovative performance, and the calculation algorithm for it is presented in the article. Comparison of regions according to these parameters allows us to distinguish four models of regional development: non-industrial, post-industrial, neoindustrial, and industrial development.

The analysis of Russian regions shows that there is no required balance between the development of industrial potential and innovative performance: the level of industrialization and the share of innovative products in the industrial output of Russian regions have weak determinism and correlation. At the same time, there is a positive dynamic shift in the structure of regional development models. The share of regions with relatively higher innovative productivity increased from $28.1 \%$ in 2014 to $29.3 \%$ in 2018 . The share of regions with a relatively higher level of industrialization increased from $42.7 \%$ in 2014 to $47.6 \%$ in 2018 . These trends positively characterize the programs for the development of industry and innovations being implemented in the Russian regions.

The article empirically proved the impossibility of transition to a new type of economy without increasing the level of its industrialization at a new technological level. 
The proposed classification of models of industrial and innovative development of regions makes it possible to assess the acceptability of the industrial policy pursued in the region from the point of view of its compliance with the challenges of the fourth industrial revolution. The theoretical and methodological provisions and practical conclusions presented in the article can serve as a basis for further research on the quality of industrial growth in the range of countries with transition economies.

\section{Acknowledgment}

The study was carried out within the framework of the state assignment of the Ministry of Education and Science of Russia (FZWN-2020-0016).

\section{References}

Benini, R., \& Czyzewski, A. (2007). Regional disparities and economic growth in Russia: new growth patterns and catching up. Economic Change and Restructuring, 40, 91-135. https://doi.org/10.1007/s10644-007-9026-0.

Cai, Y. L., Wu, G. L., \& Zhang, D. S. (2020). Does Export Trade Promote Firm Innovation? Annals of economics and finance, 21(2), 483-506. Available from: http://aeconf.com/Articles/Nov2020/aef210208.pdf.

Doroshenko, Y. A., Somina, I. V., \& Krasnokutskaia, Y. S. (2016). Evaluation of state stimulation measures for investmentinnovative activity of small enterprises in Russia. Journal of Applied Engineering Science, 14 (3), $367-376$. https://doi.org/10.5937/jaes14-10720

Doroshenko, Yu. A., Starikova, M. S., Somina, I. V., \& Malykhina, I. O. (2019). Increasing the efficiency of high-tech companies based on interactions with the entities of the innovative environment. Economy of Region, 15(4), 12791293. https://doi.org/10.17059/2019-4-24.

Ferrannini, A., Barbieri, E., Biggeri, M., \& Di Tommaso, M. R. (2020). Industrial policy for sustainable human development in the post-Covid19 era. World development, 137, 105215. https://doi.org/10.1016/j.worlddev.2020.105215.

Ferriani, S., Lazerson, M. H., \& Lorenzoni, G. (2020). Anchor entrepreneurship and industry catalysis: The rise of the Italian Biomedical Valley. Research policy, 49(8), 104045. https://doi.org/10.1016/j.respol.2020.104045.

Galbraith, G. K. (1967). The New Industrial State, Houghton Mifflin Company. Boston: Houghton Mifflin Company, 576 pp.

Goraczkowska, J. (2020). Enterprise innovation in technology incubators and university business incubators in the context of Polish industry. Oeconomia copernicana, 11(4), 799-817. https://doi.org/10.24136/oc.2020.032.

Gu, J. Q., Gouliamos, K., Lobont, O. R., \& Nicoleta-Claudia, M. (2020). Is the fourth industrial revolution transforming the relationship between financial development and its determinants in emerging economies? Technological forecasting and social change, 165, 120563. https://doi.org/10.1016/j.techfore.2020.120563.

Gubanov, S. S. (2014). Neo-industrial development model and its system algorithm. Economic and Social Changes: Facts, Trends, Forecast, 3 (33), 23-44. https://doi.org/10.15838/esc/2014.3.33.3.

Habanik, J., Grencikova, A., \& Krajco, K. (2019). The Impact of New Technology on Sustainable Development // Inzinerine ekonomika-Engineering economics, 30(1), 41-49. https://doi.org/10.5755/j01.ee.30.1.20776.

Hariharan, A. N., \& Biswas, A. (2020). Global Recognition of India's Knowledge-Based Industry Evolution Through Empirical Analysis. Journal of the knowledge economy. https://doi.org/10.1007/s13132-020-00673-x. Early access: JUL 2020.

Horta, R., Silveira, L., \& Francia, H. (2020). Innovations and exports: A new perspective for studying the Uruguayan manufacturing industry. Estudios gerenciales, 36(157), 402-414. https://doi.org/10.18046/j.estger.2020.157.3685.

Hu, G. G. (2021). Is knowledge spillover from human capital investment a catalyst for technological innovation? The curious case of fourth industrial revolution in BRIGS economies. Technological forecasting and social change, 162, 120327. https://doi.org/10.1016/j.techfore.2020.120327.

Johnston, A., \& Wells, P. (2020). Assessing the role of universities in a place-based Industrial Strategy: Evidence from the UK. Local economy, 35(4), 384-402. https://doi.org/10.1177/0269094220957977/.

Jungmittag, A. (2004). Innovations, technological specialization and economic growth in the EU. International Economics and Economic Policy (IEEP), 1, 247-273. https://doi.org/10.1007/s10368-004-0018-5.

Kallioras, D., \& Petrakos, G. (2010). Industrial growth, economic integration and structural change: evidence from the EU new member-states regions. The Annals of Regional Science, 45, 667-680. https://doi.org/10.1007/s00168-009-0296-5.

Kaneva, M., \& Untura, G. (2017). Innovation indicators and regional growth in Russia. Economic Change and Restructuring . 50, 133-159. https://doi.org/10.1007/s10644-016-9184-z.

Klyuev, N. N. (2018). Industrial and Transport Development of the Territory of Russia in the Post-Soviet Period. Geography and Natural Resources, 39, 1-9. https://doi.org/10.1134/S1875372818010018.

Kornev, A. K., Maksimtsova, S. I. \& Treshchina, S. V. (2015). Experience in world industrial development and the reindustrialization of the domestic economy. Studies on Russian Economic Development, 26, $460-469$. https://doi.org/10.1134/S107570071505007X. 
Yuri A. Doroshenko, Maria S. Starikova, Viktoriia N. Riapukhina. Models of Regional Development in Russia: Level of ...

Kroll, H., \& Neuhausler, P. (2020). Recent Trends of Regional Development in China - Technological Portfolios and Economic Growth. Zeitschrift fur wirtschaftsgeographie, 64(1), 14-27. https://doi.org/10.1515/zfw-2018-0032.

Li, K., Kim, D. J., Lang, K. R., Kauffman, R. J., \& Naldi, M. (2020). How should we understand the digital economy in Asia? Critical assessment and research agenda. Electronic commerce research and applications, 44, 101004. https://doi.org/10.1016/j.elerap.2020.101004.

Li, X., Nosheen, S., Ul Haq, N., \& Gao, X. (2021). Value creation during fourth industrial revolution: Use of intellectual capital by most innovative companies of the world. Technological forecasting and social change, 163, 120479. https://doi.org/10.1016/j.techfore.2020.120479.

Lis, A. M. (2020). Development of proximity in cluster organizations. Entrepreneurship and sustainability issues, 8(2), 116132. https://doi.org/10.9770/jesi.2020.8.2(7).

Litvinenko, V. S., \& Sergeev, I. B. (2019). Innovations as a Factor in the Development of the Natural Resources Sector. Studies on Russian Economic Development, 30, 637-645. https://doi.org/10.1134/S107570071906011X.

Madsen, J. B., Ang, J. B., \& Banerjee, R. (2010). Four centuries of British economic growth: the roles of technology and population. Journal of Economic Growth, 15, 263-290. https://doi.org/10.1007/s10887-010-9057-7.

Mateus, A., \& Martins, L. (2020). Building a mineral-based value chain in Europe: the balance between social acceptance and secure supply. Mineral economics. https://doi.org/10.1007/s13563-020-00242-3. Early access: NOV 2020.

Oplotnik, Z. J., Vojinovic, B., \& Acharya, S. (2011). Cross Border Economic Convergence and EU Integration Process. Lex localis-journal of local self-government, 9(2), 179-203. https://doi.org/10.4335/9.2.181-205(2011)

Ozak, O. (2018). Distance to the pre-industrial technological frontier and economic development. Journal of Economic Growth, 23, 175-221. https://doi.org/10.1007/s10887-018-9154-6.

Petti, C., Spigarelli, F., Lv, P., \& Biggeri, M. (2019). Globalization and innovation with Chinese characteristics: the case of the automotive industry. International journal of emerging markets, 16(2), 303-322. https://doi.org/0.1108/IJOEM02-2018-0111.

Schetinina, E. D., Starikova, M. S., Borzenkova, K. S., Chizhova, E. N., \& Androsova, G. A. (2014). The development of the business strategy based on the commercialization of innovations. International Journal of Applied Engineering Research, 9 (22), 16881-16890. Available from: https://ripublication.com/Volume/ijaerv9n22.htm.

Schneider, M. (2018). Digitalization of Production, Human Capital, and Organizational Capital. In: Harteis C. (Ed.), The Impact of Digitalization in the Workplace. Professional and Practice-based Learning (vol. 21). New York: Springer. https://doi.org/10.1007/978-3-319-63257-5_4.

Swiadek, A., \& Goraczkowska, J. (2020). The institutional support for an innovation cooperation in industry: the case of Poland. Equilibrium-quarterly journal of economics and economic policy, 15(4), 811-831. https://doi.org/10.24 136/eq.2020.035.

Tipayalai, K. (2020). Impact of international labor migration on regional economic growth in Thailand. Journal of Economic Structures, 9, 15. https://doi.org/10.1186/s40008-020-00192-7.

Ulbrych, M. (2020). Progress in Achieving Sustainable Industrial Development - the Case of the Czech Republic and Poland. Comparative economic research-central and eastern Europe, 23(4), 128-109. https://doi.org/10.18778/15082008.23.30.

van Tonder, C., Schachtebeck, C., Nieuwenhuizen, C., \& Bossink, B. (2020). A framework for digital transformation and business model innovation. Management-journal of contemporary management issues, 25(2), $111-132$. https://doi.org/10.30924/mjcmi.25.2.6.

\section{Authors' biographies}

Doroshenko Yuriy Anatolyevich Professor, Doctor of Economic Sciences in Economics and Management of the National Economy. Has more than 40 years of academic and scientific experience. His research interests are management of innovation processes in various economic systems, sustainable development of industrial enterprises. He is a member of editorial board and reviewer of several international scientific journals. He is a director of the Institute of Economics and Management in Belgorod State Technological University named after V.G. Shukhov (BSTU), chairman of the dissertation defence council. He has led various research projects related to innovation development and investment support of regional industrial systems.

Starikova Maria Sergeevna Professor, Doctor of Economic Sciences in Economics and Management of the National Economy. Has 20 years of academic and scientific experience in marketing and management. Her main research interests are adaptive and marketing enterprise management, strategic development of territories. As a professor and researcher she works at Belgorod State Technological University named after V.G. Shukhov and Belgorod National Research University. She is a member of the dissertation defence council, a reviewer for various national journals. She has participated in research projects related to regional development, territorial marketing and the competitiveness of industrial enterprises. 
Riapukhina Viktoriia Nikolaevna Associate Professor, Candidate of Economic Sciences in Economics and Management of the National Economy. Has more than 10 years of academic and scientific experience in innovation management. Her main research interests are industrial and innovative development of regional economic systems. She works at Belgorod State Technological University named after V.G. Shukhov as a lecture, researcher and director of the Institute of Serbian Language and Communication.

The article has been reviewed.

Received in April 2020; accepted in June 2021. 